\title{
Digital educational environment as a factor of developing teacher's professional reflection
}

\author{
Ambiente educacional digital como fator de desenvolvimento da \\ reflexão profissional do professor
}

\section{El entorno educativo digital como factor de desarrollo de la reflexión profesional del profesorado}

\author{
Anna Konstantinovna Oreshkina ${ }^{1}(D)$, Dmitry Vladimirovich Lukashenko ${ }^{2}(D)$ \\ Ivan Sergeyevich Samokhin ${ }^{3}$ (D), Marina Georgiyevna Sergeeva ${ }^{2}$
}

\footnotetext{
${ }^{1}$ Russian Academy of Natural Sciences, Moscow, Russian Federation; Russian Academy of Education, Moscow, Russian Federation.

${ }^{2}$ Research Institute of the Federal Penitentiary Service of the Russian Federation, Moscow, Russian Federation.

${ }^{3}$ Peoples' Friendship University of Russia (RUDN University), Moscow, Russian Federation.
}

\section{Corresponding author:}

Anna Konstantinovna Oreshkina

Email: oreshkinaa2015@yandex.ru

How to cite: Oreshkina, A. K., Lukashenko, D. V., Samokhin, I. S., \& Sergeeva, M. G. (2021). Digital educational environment as a factor of developing teacher's professional reflection. Revista Tempos e Espaços em Educação, 14(33), e16166. http://dx.doi.org/10.20952/revtee.v14i33.16166

\begin{abstract}
The article explores the problem of teachers' reflexivity, its influence on the educational process and the specifics of teachers' professional activity. The research purpose is a theoretical and empirical study of teachers' reflexivity and its developmental specifics. The main forms of reflexivity development are lecturing, training, analysis, self-analysis and testing. To improve the personality traits which are important for reflexivity development (self-awareness, communication skills, empathy, identification of professional and personal value guidelines, etc.), a teacher may also use different games and tasks, along with various methods of analyzing the lessons and his/her own contribution to them. All these resources should be included in the annual plan of an educational organization. The results of the study allow concluding about the effectiveness of the declared measures for teachers' reflexivity development. Within the changing domestic education system, one of the key challenges is training teachers who meet the requirements of the modern professional standard. A possible solution to this problem can be systematic work in an educational organization to improve the teacher's underdeveloped qualities. One of these characteristics, which can influence the improvement of the teacher's professionalism and ensure the compliance with the professional standard, is reflexivity. Along with the fact that reflexivity is among the most important components of the pedagogical activity, it is necessary to recognize the poor criterial basis for the professional
\end{abstract}


reflexivity of teachers working in educational organizations, namely the applied aspects of its development within teachers' methodological activity.

Keywords: Teachers' reflexivity. Teachers' training. Reflexive skills. Pedagogical activity.

\section{RESUMO}

O artigo explora o problema da reflexividade dos professores, sua influência no processo educacional e as especificidades da atividade profissional dos professores. O objetivo da pesquisa é um estudo teórico e empírico da reflexividade dos professores e suas especificidades de desenvolvimento. As principais formas de desenvolvimento da reflexividade são palestras, treinamento, análise, autoanálise e teste. Para melhorar os traços de personalidade que são importantes para o desenvolvimento da reflexividade (autoconsciência, habilidades de comunicação, empatia, identificação de diretrizes de valores profissionais e pessoais, etc.), um professor também pode usar diferentes jogos e tarefas, juntamente com vários métodos de análise do lições e sua própria contribuição para elas. Todos esses recursos devem ser incluídos no plano anual de uma organização educacional. Os resultados do estudo permitem concluir sobre a eficácia das medidas declaradas para o desenvolvimento da reflexividade dos professores. Dentro do sistema educacional doméstico em constante mudança, um dos principais desafios é treinar professores que atendam aos requisitos do padrão profissional moderno. Uma possível solução para este problema pode ser o trabalho sistemático em uma organização educacional para melhorar as qualidades subdesenvolvidas do professor. Uma dessas características, que pode influenciar no aprimoramento do profissionalismo do professor e garantir o cumprimento do padrão profissional, é a reflexividade. Para além do facto de a reflexividade estar entre os componentes mais importantes da actividade pedagógica, é necessário reconhecer a base criteriosa da reflexividade profissional dos professores que trabalham em organizações educacionais, nomeadamente os aspectos aplicados do seu desenvolvimento na actividade metodológica dos professores.

Palavras-chave: Reflexividade dos professores. Formação de professores. Habilidades reflexivas. Atividade pedagógica.

\section{RESUMEN}

El artículo explora el problema de la reflexividad de los profesores, su influencia en el proceso educativo y las particularidades de la actividad profesional de los profesores. El propósito de la investigación es un estudio teórico y empírico de la reflexividad de los profesores y sus aspectos específicos del desarrollo. Las principales formas de desarrollo de la reflexividad son las conferencias, la formación, el análisis, el autoanálisis y las pruebas. Para mejorar los rasgos de personalidad que son importantes para el desarrollo de la reflexividad (autoconciencia, habilidades de comunicación, empatía, identificación de pautas de valores profesionales y personales, etc.), un docente también puede utilizar diferentes juegos y tareas, junto con varios métodos de análisis de la lecciones y su propia contribución a ellas. Todos estos recursos deben incluirse en el plan anual de una organización educativa. Los resultados del estudio permiten concluir sobre la efectividad de las medidas declaradas para el desarrollo de la reflexividad docente. Dentro del cambiante sistema educativo nacional, uno de los desafíos clave es la formación de profesores que cumplan con los requisitos del estándar profesional moderno. Una posible solución a este problema puede ser el trabajo sistemático en una organización educativa para mejorar las cualidades poco desarrolladas del maestro. Una de estas características, que puede influir en la mejora de la profesionalidad del docente y asegurar el cumplimiento del estándar profesional, es la reflexividad. Junto con el hecho de que la reflexividad se encuentra entre los componentes más importantes de la actividad pedagógica, es necesario reconocer la escasa base de criterio para la reflexividad profesional de los docentes que trabajan en las organizaciones educativas, es decir, los aspectos aplicados de su desarrollo dentro de la actividad metodológica de los docentes. 
Palabras clave: Reflexividad de los profesores. Formación de profesores. Habilidades reflexivas. Actividad pedagógica.

\section{INTRODUCTION}

One of the leading goals of modern pedagogical education is developing the student's wish and ability to study throughout his/her life, systematically replenishing and enriching the professional knowledge and skills acquired in a higher educational institution. The ability to study as a need for self-improvement is fundamental to the teaching profession. The teacher should be able to address his/her inner world, to understand the motives of his/her own actions. Formed reflexive skills are crucial for the educator's self-cognition and pedagogic self-analysis. Following $\mathrm{T}$. F. Usheva (2007), we regard reflection, or self-reflection, as the process of successive actions from complication (doubting) to its discussion with oneself and the search for a solution. Thus, reflection is a complex mental ability for constant analysis and assessment of each step of one's professional activity. Using reflexive skills - intellectual, personal, communicative and cooperative - a person can control his/her own professional activity and create conditions for self-education.

In modern psychological and pedagogical science the problem of reflection as a process of cognizing (learning) one's internal mental acts and states is one of the most urgent ones. Numerous studies proved the need for reflection. Its internal nature, structure and the possibilities of its development arouse intense scientific interest. Reflection features analysis is performed at various levels (theoretical, methodological, practical), along with clarifying the specificity of these features' manifestation in different categories of specialists. Peculiar attention is given to the fact that reflection is decisive in various areas of professional activity, but this is especially true of the teaching profession, which requires analyzing children's and parents' behaviour, their interpersonal interactions, correction of conflict communication, etc. (Usheva, 2009).

Mastering reflexive skills allows the teacher to apprehend, understand and analyze his/her activity and skillfully use the means of regulating this process (a system of actions and operations leading to a successful result). This two-sided process of reflection is necessary for a modern educator to be a genuine subject of pedagogical activity (Khutorskoy, 2019).

The analysis of studies (Rogov, 1999; Illarionova, 2006; Abdullina, 1990; Shavrina, 2000; Kessel, 1980; Opper, 1989; Schroder, 1970; Gorev et al., 2018; Dolzhich \& Dmitrichenkova, 2018; Tekucheva \& Gromova, 2018) devoted to teachers' professional reflexivity (TPR) revealed the following contradictions.

1. Regardless of the subject area, there are practically no means and methods which may be used to establish the criteria, their indicators and reflexivity levels for practicing teachers.

2. Having an access to multiple works on studying professional reflexivity, modern teachers are not provided with relevant methodological recommendations (those suitable for implementation in an educational organization and aimed at developing all criteria for teachers' reflexivity assessment.

This article will consider the reflexivity, namely TPR as a constituent element of reflection, which is a personality trait that can develop under favourable conditions (Illarionova, 2007).

\section{LITERATURE REVIEW}

Reflection is the basic personality characteristic, enabling a subject to apprehend and regulate his/her life activity. Self-analysis and self-esteem of one's own personality are continuously connected with reflection, which makes it possible to assess one's thinking and activity, allows a person to analyze the past and plan the future, predicting possible results in the most effective way (Zimnyaya, 2010).

Reflexivity, including TPR, has been an attractive scientific topic for several decades. There are numerous works on the types of reflexivity, its role in forming a human's personality and a 
teacher's professional self (Bandler \& Grinder, 2001; Gaude, 1989; Kaminski, 1987; Roht, 1972; Blinova et al., 2018).

Thus, TPR has a significant impact on the educator's professional thinking, the nature of professional interactions, professional self-determination and the attitude towards his/her own professional self-development (Moreno, 1972).

TPR requires its purposeful improvement. Contemporary scientific literature offers numerous forms and methods aimed at developing personal qualities that form the basis of reflexive skills, along with mastering the modes and techniques of reflexive thinking and reflexive activity.

The methodological work involves the analysis, self-assessment and mutual assessment of professional actions and pedagogical interaction according to pedagogical competencies (both with groups and with individuals).

The teacher's understanding of the educational process, the internal focus on his/her professional development, the analysis of his/her professional deficiencies, successes and failures allow enriching professional skills, choosing effective pedagogical technologies and techniques to achieve professional and personal results.

\section{PROPOSED METHODOLOGY}

The chosen methodology and algorithm involve conducting a complex psychological and pedagogical experiment, assessing the stated parameters and analyzing them statistically. The study of students' reflectivity was conducted in the Institute of Foreign Languages of the Peoples' Friendship University of Russia (RUDN University).

The main problem in the study of reflexivity is its criteria. Relying on the works by N. Ya. Saygushev, O. A. Vedeneyeva and Yu. B. Melekhova (2018), we developed a criterion-diagnostic research base, presented in Table 1.

Table 1. Criteria, indicators and levels of TPR formation

\begin{tabular}{|c|c|c|c|c|}
\hline \multirow{2}{*}{ Criteria } & \multirow[t]{2}{*}{ Indicators } & \multicolumn{3}{|c|}{ Levels of formation } \\
\hline & & High & Average & Low \\
\hline
\end{tabular}




\begin{tabular}{|c|c|c|c|c|}
\hline $\begin{array}{l}\text { Value- } \\
\text { motivational }\end{array}$ & $\begin{array}{l}\text { the nature of professional } \\
\text { activity motivation; } \\
\text { the level of assessing the } \\
\text { ability for self-development } \\
\text { and self-education }\end{array}$ & $\begin{array}{l}\text { The teacher has a } \\
\text { clearly perceived } \\
\text { internal motive, a } \\
\text { stable positive and } \\
\text { constructive attitude } \\
\text { towards professional } \\
\text { activity, which persists } \\
\text { even in a situation of } \\
\text { failure. }\end{array}$ & $\begin{array}{l}\text { The teacher recognizes } \\
\text { the external motive and } \\
\text { correlates it with his/her } \\
\text { own needs, which } \\
\text { underlies the formation of } \\
\text { the need for professional } \\
\text { activity, self-development } \\
\text { and self-education }\end{array}$ & $\begin{array}{l}\text { The teacher does } \\
\text { not have internal } \\
\text { motivation, only } \\
\text { external one } \\
\text { f }\end{array}$ \\
\hline
\end{tabular}

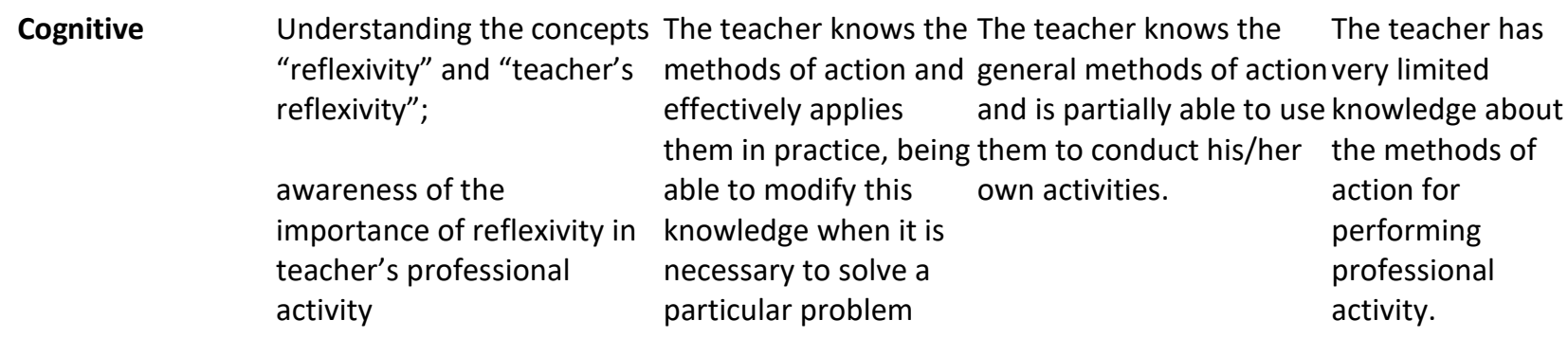

Activity-based Ability to conduct the reflexive analysis (introspection) of one's pedagogical activity and the perception of one's professional activity by other participants in the educational process

Ability to highlight one's professionally significant qualities, abilities, needs ando conditions using reflexive skills and experience
The teacher evaluates The teacher tries to assess The teacher does his/her own capabilities and his/her capabilities before not know how to solving a new task; appliesevaluate his/her independently creates the learned methods of actions, performs new methods of action action, but does not individual in responding to a new modify them to solve a challenge; realizes the new task; corrects errors composition and without assistance; interconnection; principles of creating a controls new problem-solving the students' problemmethod and its solving activity via other participants of professional activity; is critical of external evaluation.

problem specification detects the errors caused by the discrepancy between the learned scheme and the specification of a new problem; makes adjustments to the scheme before the solution process operations without does not control actions and does not detect errors (a noticed mistake is corrected irresolutely, without confidence; needs external assessment, but perceives it uncritically. 


\begin{tabular}{|c|c|c|}
\hline Value-motivational & $\begin{array}{l}\text { The type of professional activity motivation } \\
\text { The level of assessing the ability for self- } \\
\text { development and self-education }\end{array}$ & $\begin{array}{l}\text { Test "Motivation of professional } \\
\text { activity" by K. Zamfir modified by A. } \\
\text { Rean; the test by V.I. Andreyev } \\
\text { assessing the need for self- } \\
\text { development and self-education } \\
\text { proposed }\end{array}$ \\
\hline Cognitive & $\begin{array}{l}\text { Understanding the concepts } \\
\text { "reflexivity" and "teacher's reflexivity" } \\
\text { Understanding the significance of reflexivity in the } \\
\text { teacher's professional activity }\end{array}$ & $\begin{array}{l}\text { The test by T.V. Yurova for } \\
\text { determining the development level of } \\
\text { TPR cognitive criterion }\end{array}$ \\
\hline Activity-based & $\begin{array}{l}\text { Ability to conduct the reflexive analysis } \\
\text { (introspection) of one's pedagogical activity and the } \\
\text { perception of one's professional activity by other } \\
\text { participants in the educational process } \\
\text { Ability to highlight one's professionally significant } \\
\text { qualities, abilities, needs and conditions using } \\
\text { reflexive skills and experience }\end{array}$ & $\begin{array}{l}\text { Assessment of TPR formation level by } \\
\text { O.V. Kalashnikova; self-assessment } \\
\text { and peer appreciation } \\
\text { through micro-training }\end{array}$ \\
\hline
\end{tabular}

The research algorithm is presented in Table 3.

Table 3. Algorithm of actions within the experiment

\begin{tabular}{l} 
Algorithm of actions \\
\hline 1) assessment of professional reflexivity elements \\
2) realization of formative stage events \\
3) repeated assessment of professional reflexivity elements
\end{tabular}

\section{RESULT ANALYSIS}

The research involving 47 teachers was conducted in the Institute of Foreign Languages of Peoples' Friendship University of Russia (RUDN University). The article will provide the comparative analysis of diagnostic data before and after the activities presupposed by the formative stage of the study.

The leading factor in TPR development can be the creation and implementation of the set of special classes that will include the following sections.

The basic section is oriented towards developing the cognitive criterion of TPR;

The section for resource activation should develop the value-motivational criterion for the participants' professional reflexivity;

The section for achievement reflection will ensure the development of TPR activity criterion.

The main forms of reflexivity development are lecturing, training, analysis, self-analysis and testing. To improve the personality traits which are important for reflexivity development (selfawareness, communication skills, empathy, identification of professional and personal value guidelines, etc.) a teacher may also use different games and tasks, along with various methods of analyzing the lessons and his/her own contribution to them. All these resources should be included in the annual plan of an educational organization (Vasbieva et al., 2018; Bírová et al., 2018; Volkova \& Panchenko, 2018). 
The authors conducted the repeated assessment to identify changes in the development level of three TPR criteria: value-motivational, cognitive and activity-based.

Table 4 presents the results of the comparative analysis of teachers' motivational preferences at different assessment stages.

Table 4. Changes in teachers' motivational preferences

\begin{tabular}{lcc}
\hline \multirow{2}{*}{ Motivational preferences } & \multicolumn{2}{c}{ Average score } \\
\cline { 2 - 3 } & $\begin{array}{c}\text { Results of the reference } \\
\text { assessment }\end{array}$ & $\begin{array}{c}\text { Results of the ultimate } \\
\text { assessment }\end{array}$ \\
\hline Earnings & 3,812 & 3,771 \\
Promotion ambitions & 2,513 & 2,832 \\
Aspiration to avoid criticism from the superior or the & 3,176 & 2,815 \\
colleagues & & 2,442 \\
Aspiration to avoid possible punishment or other & 3,161 & 4,331 \\
troubles & & 4,594 \\
Need for social prestige and respect & 4,172 & 4,532 \\
satisfaction from the process itself and the result of work & 4,252 & 4,373 \\
possibility of the most complete self-realization in this & & \\
particular activity & & \\
\hline
\end{tabular}

The assessment which was conducted at the end of the study revealed changes in all indicators. It is especially important to emphasize the decreasing significance of the indicators "aspiration to avoid criticism from the superior or the colleagues" and "aspiration to avoid possible punishment or other troubles" (Sharonova et al., 2018, p. 117).

The significance of the indicators "satisfaction from the process itself and the result of work" and "possibility of the most complete self-realization in this particular activity" for all teachers became very significant.

Changes in the level of evaluating the ability for self-development and self-education are presented in Table 5.

Table 5. Changes in the level of evaluating the ability for self-development and self-education (the test proposed by V.I. Andreev)

\begin{tabular}{lcc}
\hline \multirow{2}{*}{$\begin{array}{c}\text { Level of ability for self-development and } \\
\text { self-education }\end{array}$} & Number of teachers with the corresponding level in \% \\
\cline { 2 - 3 } & Results of the reference assessment & Results of the ultimate assessment \\
\hline Very low & 0 & 0 \\
Low & 1 & 0 \\
Below average & 5 & 0 \\
Slightly below average & 17 & 3 \\
Average & 15 & 9 \\
Slightly above average & 7 & 16 \\
Above average & 2 & 13 \\
High & 0 & 6 \\
Very high & 0 & 0 \\
TOTAL & 47 & 47 \\
\hline
\end{tabular}

The final assessment of the level of evaluating the ability for self-development and selfeducation revealed the improvement of this indicator in all teachers working at the educational 
organization. Thanks to the classes, six teachers were able to show the high level of the ability for self-improvement and self-education. There are no teachers with the low or below-average level of this ability.

Thus, the testing of the achieved results associated with the value-motivational criterion for TPR development confirmed the correctness of the forms, methods and exercises that we had chosen to improve the assessment process.

The repeated analysis of the cognitive TPR criterion revealed the following changes (see Table 6).

Table 6. Changes in the level of TPR cognitive criterion formation (the test proposed by T.V. Yurova)

\begin{tabular}{lll}
\hline Level of the criterion formation & Number of people \\
\cline { 2 - 3 } & Results of the reference assessment & Results of the ultimate \\
Low & 8 & 0 \\
Average & 33 & 0 \\
High & 6 & 47 \\
\hline
\end{tabular}

At the end of the experiment all participants have the high level of TPR cognitive criterion formation. Each teacher is familiar with the concept of reflexivity, correlates this personality trait with his/her professional activity and considers it a socially significant characteristic. The educators realized the usefulness of reflexive behaviour and began to pay more attention to the consequences of their actions (or inaction).

The final assessment of the activity-based component considered the methodology for determining the level of TPR formation proposed by O.V. Kalashnikova.

The assessment results are presented in Table 7.

Table 7. Changes in the number of teachers according to the level of TPR formation (the test proposed by O.V. Kalashnikova)

\begin{tabular}{lll}
\hline Level of the criterion formation & Number of people \\
\cline { 2 - 3 } & Results of the reference assessment & $\begin{array}{l}\text { Results of the ultimate } \\
\text { assessment }\end{array}$ \\
\hline Low & 10 & 0 \\
Average & 20 & 27 \\
High & 17 & 20 \\
\hline
\end{tabular}

The assessment showed the significant improvement of the TPR formation level. At the end of the experiment all teachers have the average or high level of TPR development (according to the test proposed by O.V. Kalashnikova).

The changes in the level of the activity-based component of TPR development were also evaluated within the section "Achievement reflection" at the second lesson "How do I carry out reflection in my professional activity?" These changes were assessed when teachers were discussing the issues of pedagogical analysis and self-analysis.

During the lessons the teachers tried to use the knowledge gained within the previous classes. The basis for determining the ultimate development level of TPR activity-based component was the number of coinciding responses given by the analyzed teacher and his/her analyzers. The other factor was the subjective perception of this person's results by the colleagues.

Therefore, 5-6, 3-4 and 0-2 coinciding answers indicate (correspondingly) the high, average and low levels of the activity component development. The assessment results are presented in Table 8. 
Table 8. Changes in the distribution of teachers by their proficiency in conducting reflexive analysis (self-analysis) and perception of themselves by the other participants of the educational process (their colleagues).

\begin{tabular}{lcc}
\hline & Level of skill formation & \multicolumn{2}{l}{ Number of people } \\
\cline { 2 - 3 } & Results of the reference assessment & \multicolumn{2}{l}{$\begin{array}{l}\text { Results of the ultimate } \\
\text { assessment }\end{array}$} \\
\hline Low & 12 & 0 \\
Average & 23 & 31 \\
High & 12 & 16 \\
\hline
\end{tabular}

The final assessment of the formation level of TPR activity-based component revealed the absence of teachers with a low level of the studied characteristic. All teachers mastered the action methods aimed at the reflective analysis of their own professional activities. The educators are able to find and independently correct mistakes caused by the discrepancy between the learned action scheme and the conditions of the new task. Besides, they are critical of external assessment, are able to assess themselves and others within professional activity, and can estimate their potentialities before starting to solve a new task.

Therefore, the conducted classes on TPR development ensured the improvement of the teachers' professional skills.

Relying on the analysis of the formative stage results, we made the following conclusions.

1. The created methodological conditions for the development of all three TPR criteria (valuemotivational, cognitive and activity-based) proved to be productive.

2. The selected forms and methods for TPR criteria development were effective, which was confirmed by the final assessment of these criteria (value-motivational, cognitive and activity-based).

3. Purposeful work on TPR development within the methodological support will increase teachers' competence in solving professional problems, and will allow designing optimal pedagogical conditions and means to achieve high educational results.

\section{CONCLUSION}

The study is devoted to the urgent problem of developing TPR as a mechanism of personal and professional self-improvement. The system of working on TPR development involves the creation of special conditions within methodological activity. Examining this problem made it possible to draw a number of general conclusions.

Being a psychological and pedagogical concept, TPR predetermines the dual nature of its study. First of all, it is regarded as the teacher's personal quality, reflecting his/her ability to manage the development of the relevant competencies, i.e. to demonstrate personal and professional growth. Besides, it may be seen as a way to fulfill the educator's work functions, aimed primarily at improving the quality of students' education.

The scientific literature proposes different approaches to the possibility of TPR development, for example, through the organization of the teacher's activities to the reflective analysis of his/her professional activity and himself or herself as its subject. This approach implies such forms as reference programmes for monitoring one's actions, keeping a diary, recording a lesson on a device, a variety of game techniques and a case method. The second approach to the possibility of TPR development, aimed at reorienting or correcting the teachers' professional and personal attitudes, is solved in the context of training.

TPR development presupposes mastering the following components: value-motivational, cognitive and activity-based. 
The psychological basis for TPR development is self-analysis, self-determination and selfdevelopment of teachers as the subjects of pedagogical activity.

The content and forms of methodological work on TPR development should be focused on acquiring professional reflexive knowledge, along with forming the skills that help to analyze one's pedagogical activity and the attitude to this analysis.

The problem of TPR development is diverse, and our study does not cover the full range of problematic issues in this area. Further investigation of this topic may include studying the introduction of reflexive elements into the educational practice and exploring TPR influence on teachers' professional growth, their effectiveness, etc.

Authors' Contributions: Anna Konstantinovna Oreshkina: conception and design, acquisition of data, analysis and interpretation of data, drafting the article, critical review of important intellectual content. Dmitry Vladimirovich Lukashenko: conception and design, acquisition of data, analysis and interpretation of data, drafting the article, critical review of important intellectual content. Ivan Sergeyevich Samokhin: conception and design, acquisition of data, analysis and interpretation of data, drafting the article, critical review of important intellectual content. Marina Georgiyevna Sergeeva: conception and design, acquisition of data, analysis and interpretation of data, drafting the article, critical review of important intellectual content. All authors have read and approved the final version of the manuscript.

Ethics Approval: Not applicable.

Acknowledgments: Not applicable.

\section{REFERENCES}

Abdullina, O. A. (1990). Obshchepedagogicheskaya podgotovka uchitelya v sisteme vysshego obrazovaniya [General pedagogical training of teachers in the higher education system]. Moscow: Prosveshcheniye, $141 \mathrm{p}$.

Bandler, R., \& Grinder, D. (2001). Neue Wege der Kurrzeit-Therapie [New ways of therapy]. Berlin: Junfermannsche Verlags, $240 \mathrm{p}$.

Bírová, J., Kružlík, P., Kalimullin, A., Sokolova, N., Haroun, Z., Králik, R., \& Vasbieva, D. (2018). Mathematical and Statistical Bibliometric Indicators for Scholars in the Field of Romance Languages and Linguistics. EURASIA: Journal of Mathematics, Science and Technology Education, 14(12), em1638. https://doi.org/10.29333/ejmste/97826

Blinova, S., Dugina, T., \& Zabolotskikh, A. (2018). Teaching mixed nationality groups (on the example of students from the Northern Caucasus region). In: INTED2018: Proceedings of the 12th International Technology, Education and Development Conference, Valencia, Spain, pp. 7977-7982.

Dolzhich, E., \& Dmitrichenkova, S. (2018). Computer science terminology (a case study of the Spanish language). In: INTED2018: Proceedings of the 12th International Technology, Education and Development Conference, Valencia, Spain, pp. 2556-2559.

Gaude, P. (1989). Selbstbewertung und Beratung in der Lehrerausbildung (SBL) ein angewandtes Forschungsprojekt [Self-assessment and consulting in teacher training: an applied research project]. Unterrichts wissenschaft [Teaching Science], 1(17), 47-59.

Gorev, P., Telegina, N., Karavanova, L., \& Feshina, S. (2018). Puzzles as a didactic tool for development of mathematical abilities of junior schoolchildren in basic and additional mathematical education. EURASIA: Journal of Mathematics, Science and Technology Education, 14(10), 178-185. http://dx.doi.org/10.29333/ejmste/93675

Illarionova, T. F. (2006). Kollektivnyye uchebnyye zanyatiya kak sposob razvitiya refleksii budushchikh pedagogov [Collective training sessions as a way of developing the reflection of future teachers]. Sibirskiy uchitel' [Siberian Teacher], 2, 20-23.

Illarionova, T.F. (2007). Diagnostika refleksivnykh umeniy pedagogov [Assessment of teachers' reflexive skills]. Kollektivnyy sposob obucheniya [Collective Way of Teaching], 9, 103-113.

Kaminski, G. (1987). Einige Reflexionen uber Fforscher-Reflexionen uber Lehrer-Reflexionen [Some reflections on researcher's reflections on teacher's reflections]. Unterrichts wissenschaft [Teaching Science], 15(3), 321-331. 
Kessel, W. (1980). Selbstbild-Fremdbild-Differenzender Lehrerund Identifika-tionsbereitsschaft der Schuler [Teachers' self-education and external image and students' identification readiness]. Beitrag zum 22 ICP [Contribution to the $22^{\text {nd }}$ ICP]. Leipzig.

Khutorskoy, A. V. (2019). Pedagogika [Pedagogy]: A textbook for higher education institutions. Saint Petersburg: Piter, $608 \mathrm{p}$.

Kuzmina, N. V. (1970). Metody issledovaniya pedagogicheskoy deyatel'nosti [Methods of studying pedagogic activity]. Leningrad: Leningrad State University, 114 p.

Moreno, J. L. (1972). Psychodrama. In: Kaplan, H. I., Sadock, B. J. (Eds.). Comprehensive Group Psychotherapy. Baltimore: Williams and Wilkins, pp. 460-500.

Opper, K.-H. (1989). Paradigmenwechsel oder die Muhen, sich im Sattel zu halten [Paradigm shift or the effort to keep yourself in the saddle]. In: Hofling, S., Butollo, W. (Eds.). Psychologie fur Menschenwurde und Lebensqualitat [Psychology for Human Diognity and Quality of Life]. Vol. 2. Munchen: Deutscher Psychologen Verlag.

Rogov, Ye. I. (1999). Nastol'naya kniga prakticheskogo psikhologa [Handbook of a practical psychologist]. Vol. 2: Rabota psikhologa so vzroslymi. Korrektsionnyye priyemy i uprazhneniya [A psychologist's work with adults. Correctional techniques and exercises]. Moscow: VLADOS, $480 \mathrm{p}$.

Roht, W. (1972). Berufszufriedenheit im Lehrerberuf [Job satisfaction in the teaching profession]. Westermanns Padagogische Beitrage [Westermann's educational contributions], 24, 640-646.

Saygushev, N. Ya., Vedeneyeva, O. A., \& Melekhova, Yu. B. (2018). Potrebnost' v pedagogicheskoy refleksii kak usloviye professional'nogo samorazvitiya budushchego spetsialista v sisteme gumanitarnogo obrazovaniya [The need for pedagogical reflection as a condition for the professional self-development of a future specialist in the system of humanitarian education]. Problemy sovremennogo pedagogicheskogo obrazovaniya [Issues of Modern Pedagogic Education], 59(4), 213-216.

Schroder, H. (1970). Lehrerspersonlichkeit und Erziehungswirklichkeit [Teacher's personality and educational reality]. Berlin.

Sharonova, S., Trubnikova, N., \& Sokolova, N. (2018). Interpreting religious symbols as basic component of social value formation. European Journal of Science and Theology, 14(3), 117-129.

Shavrina, O. Yu. (2000). Formirovaniye pedagogicheskoy refleksii v podgotovke budushchikh uchiteley [Formation of pedagogical reflection in the preparation of future teachers]. PhD thesis abstract (psychology). Ufa, 24 p.

Tekucheva, I. V., \& Gromova, L. Y. (2016). On present state of teaching Russian language in Russia. International Journal of Environmental and Science Education, 11(14), 6504-6511.

Usheva, T. F. (2007). Usloviya formirovaniya refleksii studentov pedagogicheskogo vuza [Conditions for the formation of reflection in students of a pedagogical university]. Vyssheye obrazovaniye segodnya [Higher Education Today], 10, 42-44.

Usheva, T. F. (2009). Pedagogicheskiye usloviya formirovaniya refleksivnykh umeniy studentov $v$ protsesse kollektivnykh uchebnykh zanyatiy [Pedagogical conditions for the formation of students' reflexive skills within collective training]. Sibirskiy pedagogicheskiy zhurnal [Siberian Pedagogic Journal], 5, 140-152.

Vasbieva, D. G., Sokolova, N. L., Masalimova, A. R., Shinkaruk, V. M., \& Kiva-Khamzina, Y. L. (2018). Exploring the EFL Teacher's Role in a Smart Learning Environment - A Review Study. XLinguae, 11(2), 265-274.

http://dx.doi.org/10.18355/XL.2018.11.02.21

Volkova, Y., \& Panchenko, N. (2018). Discourse variation of the concepts of destructive emotions. Vestnik Rossiiskogo Universiteta Druzhby Narodov = Russian Journal of Linguistics, 22(1), 175-194. https://doi.org/10.22363/2312-91822018-22-1-175-194

Zimnyaya, I. A. (2010). Pedagogicheskaya psikhologiya [Pedagogic psychology]: A textbook for higher education institutions. Moscow: Moscow Psychological and Social Institute; Voronezh: MODEK, 447 p.

Received: 02 June 2021 | Accepted: 12 July 2021 | Published: 31 July 2021

This is an Open Access article distributed under the terms of the Creative Commons Attribution License, which permits unrestricted use, distribution, and reproduction in any medium, provided the original work is properly cited. 